\title{
STUDI PENYUSUNAN PROFIL DAERAH IRIGASI JAMBO REUHAT
}

\author{
Cut Rahmawati ${ }^{1}$ \\ 1) Program Studi Teknik Sipil, Fakultas Teknik, Universitas Abulyatama \\ Jl. Blang Bintang Lama Km 8,5 Lampoh Keude Aceh Besar, \\ email: profestama7@yahoo.co.id
}

\begin{abstract}
The purpose of compilation study of Jambo Reuhat irrigation area profile was to collect correct and actual data and information as input in planning P3A organizational empowerment/"Keujruen Blang" program to improve the management of participatory irrigation in Jambo Reuhat Irrigation Area based on potential local resources. Jambo Reuhat Irrigation Area is located in the administrative area of East Aceh Regency which includes Idi Rayeuk, Idi Tunong, Darul Ihsan and Banda Alam Sub-districts. The method used was descriptive research which is case study and field study. SWOT analysis was performed to formulate strategy and policy which would be used. This study also distributed questionnaires to 12 (twelve) P3A in Jambo Reuhat Irrigation Area. The socio-economic aspect in Jambo Reuhat Irrigation Area should increase business opportunity for productive economy which could be developed optimally by agricultural intensification, improving technology mastery pre- and post-harvest, agronomy and agricultural business diversification. In organizational aspect, the status of P3A/'Keujruen Blang" should be raised to legal entity and have legality in performing works related to improving the performance of Jambo Reuhat Irrigation Area. In technical aspect, damaged irrigation channels and buildings with decreased functions should be. In agricultural business aspect, mastery and application method of efficient technology in crop processing, crop preparation to post-harvest should be improved. Potential local resource which should be developed was animal farming to support agricultural activities and to be integrated optimally with activities to improve farmers' economy.
\end{abstract}

Keywords : profile of irrigation area, SWOT, P3A empowerment

\begin{abstract}
Abstrak: Tujuan studi penyusunan profil Daerah Irigasi Jambo Reuhat adalah untuk mendapatkan data dan informasi yang tepat serta aktual sebagai masukan dalam proses perencanaan program pemberdayaan organisasi P3A/Keujruen Blang menuju peningkatan kinerja pengelolaan irigasi partisipatif pada Daerah Irigasi Jambo Reuhat berdasarkan potensi sumber daya lokal. Daerah Irigasi Jambo Reuhat berada dalam wilayah administrasi Kabupaten Aceh Timur yang meliputi Kecamatan Idi Rayeuk, Idi Tunong, Darul Ihsan dan Banda Alam. Metode yang digunakan adalah penelitian deskriptif yang merupakan penelitian kasus dan penelitian lapangan (case study and field study). Dalam Studi ini juga disebarkan quesioner pada 12 (dua belas) P3A yang ada di D.I Jambo Reuhat. Dalam aspek sosial ekonomi pada D.I Jambo Reuhat perlu dilakukan peningkatan peluang usaha ekonomi produktif yang dapat dikembangkan secara maksimal melalui intensifikasi pertanian, peningatan kemampuan penguasaan teknologi pra dan pasca panen, agronomi dan diversifikasi usaha tani. Dalam aspek kelembagaan perlu dilakukan Peningkatan status P3A/Keujruen Blang menjadi berbadan hukum dan memiliki legalitas dalam setiap pelaksanaan pekerjaan yang berhubungan dengan peningkatan kinerja D.I Jambo Reuhat. Dalam aspek teknis perlu dilakukan perbaikan jaringan irigasi yang sudah rusak dan perbaikan bangunan yang telah menurun fungsinya. Dalam aspek usaha tani perlu dilakukan peningkatan penguasaan dan metode aplikasi teknologi tepat guna pada tahapan pengolahan tanam, persiapan tanam sampai ke tahapan pasca panen. Potensi sumber daya lokal yang perlu dikembangkan adalah peternakan untuk mendukung kegiatan pertanian dan terintegrasi secara optimal dengan kegiatan peningkatan ekonomi petani.
\end{abstract}

Kata kunci : profil daerah irigasi, SWOT, kelembagaan P3A 
Pengelolaan irigasi merupakan salah satu sektor pendukung utama bagi keberhasilan pembangunan pertanian, terutama dalam rangka meningkatkan produksi pangan khususnya beras. Namun dalam perkembangannya kinerja pengelolaan irigasi telah mengalami penurunan yang disebabkan oleh beberapa hal seperti : kegiatan perawatan; perbaikan atau pemeliharaan jaringan irigasi yang tertunda (divert maintenance); kerusakan karena ulah manusia dan bencana alam. Hal-hal tersebut menyebabkan kerusakan pada jaringan irigasi. Selain itu, pengembangan sektor irigasi membutuhkan gambaran detail dan akurat mengenai kondisi irigasi, kendala yang dihadapi, kemungkinan pengembangan serta tantangan yang muncul.

Penyusunan profil irigasi merupakan kegiatan yang bertujuan untuk meningkatkan kinerja irigasi dalam menunjang ketahanan pangan melalui perbaikan sektor kelembagaan, sistim operasional, infrastruktur pendukung dan teknologi pertanian dengan mengoptimalkan budaya pertanian setempat.

Instrumen perencanaan dalam konteks kebutuhan program cukup banyak dikembangkan untuk pemberdayaan masyarakat. Salah satu instrumen yang dapat digunakan adalah Dokumen Profil Daerah Irigasi, dalam konteks tersebut secara konseptual dapat didefinisikan sebagai gambaran informasi atau data mengenai keadaan sosial, ekonomi, teknis, kelembagaan pada suatu daerah irigasi yang dibutuhkan untuk proses perencanaan pengelolaan irigasi. Pelaksanaan kegiatan tersebut perlu diselenggarakan secara tepat sesuai kebutuhan. Ketidaktepatan dalam pelaksanaan dapat menyebabkan deviasi (penyimpangan) dalam merumuskan pembuatan program yang akan direncanakan. Oleh karena itu diperlukan suatu panduan yang dapat memberikan penjelasan, pemahaman, dan langkah-langkah kegiatan yang diperlukan pada penyusunan profil suatu daerah irigasi sehingga diperoleh informasi yang akurat, aktual dan tepat untuk merencanakan suatu program menuju peningkatan kinerja pengelolaan irigasi pada suatu daerah irigasi. Untuk mendapatkan gambaran informasi atau data mengenai keadaan sosial, ekonomi, teknis, dan kelembagaan pada Daerah Irigasi perlu disusun Profil Daerah Irigasi.

Tujuan Studi Penyusunan Profil Daerah Irigasi Jambo Reuhat adalah untuk mendapatkan data dan informasi yang tepat serta aktual sebagai masukan dalam proses perencanaan program pemberdayaan organisasi P3A/Keujeuruen Blang menuju peningkatan kinerja pengelolaan irigasi partisipatif pada suatu daerah irigasi berdasarkan potensi sumber daya lokal melalui beberapa kegiatan sebagai berikut:

a. Penyusunan profil sosial dan ekonomi, serta mengidentifikasi potensi sumber daya lokal;

b. Penyusunan profil teknis pengelolaan irigasi (operasi, pemeliharaan dan 
rehabilitasi jaringan irigasi), termasuk gambaran ketersediaan air, kondisi fisik dan fungsi jaringan irigasi, serta lahan pertanian beririgasi;

c. Penyusunan profil kelembagaan dengan mengidentifikasi kelembagaan lokal yang ada, kebutuhan pembentukan organisasi Keujruen Blang dan upaya pengembangannya berdasarkan hasil penelusuran kebutuhan petani; dan

d. Mengidentifikasi kebutuhan pelatihan dalam rangka meningkatkan kemampuan organisasi Keujruen Blang baik pada aspek teknis, kelembagaan maupun usaha tani dan usaha ekonomi produktif.

Secara khusus penyusunan profil suatu daerah irigasi akan berguna :

a. Bagi masyarakat petani pemakai air (KEUJEURUEN BLANG) sekurangkurangnya adalah sebagai dasar pertimbangan dalam :

- Proses perencanaan kegiatan pembentukan/penyegaran

(revitalisasi/restrukturisasi/ reorganisasi) dan pengembangan organisasi KEUJEURUEN BLANG pada suatu daerah irigasi;

- Pengembangan legalisasi badan hukum organisasi KEUJEURUEN BLANG;

- Kebutuhan pelatihan baik aspek teknis, kelembagaan maupun usaha tani dan usaha ekonomi produktif berbasis potensi lokal;

- Peningkatan pelayanan kebutuhan anggota organisasi $\mathrm{P} 3 \mathrm{~A} / \mathrm{GP} 3 \mathrm{~A} /$ IP3A; dan

- Penyusunan usulan Dana Pengelolaan Irigasi (DPI) dan Kerjasama Pengelolaan Irigasi (KSP) bersama Satuan Kerja Perangkat Daerah (SKPD) terkait dengan irigasi.

b. Bagi Komisi Irigasi sekurang-kurangnya adalah sebagai dasar pertimbangan dalam:

- Penyusunan dan pelaksanaan koordinasi perencanaan pengelolaan irigasi partisipatif dalam menunjang kinerja pembangunan daerah;

- Merumuskan kebijakan untuk mempertahankan dan meningkatkan kondisi dan fungsi jaringan irigasi;

- Merumuskan pola dan rencana tata tanam pada daerah irigasi, serta rencana tahunan penyediaan air irigasi;

- Merumuskan rencana tahunan pembagian dan pemberian air irigasi bagi pertanian dan keperluan lainnya;

- Memberikan rekomendasi prioritas alokasi Dana Pengelolaan Irigasi (DPI) yang diusulkan oleh organisasi KEUJEURUEN BLANG pada suatu daerah irigasi;

- Memberikan pertimbangan dalam menjaga alih fungsi lahan ber-irigasi;

- Penyusunan dan pelaksanaan kegiatan monitoring dan evaluasi kinerja pengelolaan irigasi 
partisipatif dan pemberdayaan organisasi KEUJEURUEN BLANG.

c. Bagi Satuan Kerja Perangkat Daerah (SKPD) terkait dengan irigasi sekurangkurangnya adalah sebagai dasar pertimbangan dalam:

- Penyusunan rencana strategis pengelolaan irigasi partisipatif dan pemberdayaan organisasi Keujruen Blang;

- Penyusunan program kerja pengelolaan irigasi partisipatif di tingkat sistem utama (primer dan sekunder);

- Menjaga dan meningkatkan kondisi fisik dan tingkat kefungsian jaringan;

- Menetapkan Dana Pengelolaan Irigasi (DPI) yang diusulkan oleh organisasi KEUJRUEN BLANG pada suatu daerah irigasi

- Fasilitasi kebutuhan pelatihan untuk organisasi KEUJRUEN BLANG baik aspek teknis, kelembagaan maupun usaha tani dan usaha ekonomi produktif berbasis potensi lokal;

- Penetapan penyusunan Angka Kebutuhan Nyata Pengelolaan Irigasi (AKNPI/AKNOP) pada tingkat sistem utama (jaringan primer dan sekunder);

- Peningkatan pelayanan kebutuhan air irigasi bagi organisasi $\mathrm{P} 3 \mathrm{~A} /$ GP3A/IP3A; dan

- Penetapan Kerjasama Pengelolaan
Irigasi (KSP) bersama Satuan Kerja Perangkat Daerah (SKPD) terkait dengan irigasi;

- Mencegah alih fungsi lahan beririgasi; dan

- Penyusunan dan pelaksanaan kegiatan monitoring dan evaluasi kinerja pengelolaan irigasi partisipatif dan pemberdayaan KEUJRUEN BLANG.

d. Bagi pemangku kepentingan lainnya terkait dengan irigasi sekurang-kurangnya adalah sebagai dasar pertimbangan dalam:

- Memberikan fasilitasi bantuan sesuai kebutuhan organisasi KEUJRUEN BLANG.

- Membangun hubungan kerjasama berdasarkan kesetaraan dan kemitraan baik dalam kegiatan pengelolaan irigasi maupun pengembangan kelembagaan organisasi KEUJRUEN BLANG pada suatu daerah irigasi.

\section{KAJIAN PUSTAKA}

Kegiatan "Penyusunan Profil Daerah Irigasi" yang mengambil lokasi Daerah Irigasi Jambo Reuhat sejalan dengan sistem rencana pembangunan lainnya dan mengacu pada ketentuan perundangan yang berlaku. Acuan yang menjadi landasan teknis kegiatan ini antara lain Undang-undang No. 11 Tahun 1974 tentang Pengairan, Undang-Undang No. 32 Tahun 2004 tentang Pemerintahan Daerah; Undang-Undang No. 25 Tahun 2004 tentang Sistem Perencanaan dan Pembangunan 
Nasional; Undang-Undang No. 41 Tahun 2009 tentang Perlindungan Lahan Pertanian Pangan Berkelanjutan; serta Peraturan Pemerintah No. 38 Tahun 2007 tentang Pembagian Urusan Pemerintahan Antara Pemerintah, Pemerintahan Daerah Provinsi, Dan Pemerintahan Daerah Kabupaten/Kota.

Sejalan dengan itu perkembangan reformasi kebijakan pengelolaan irigasi sebagaimana yang diamanatkan dalam Peraturan Pemerintah No. 20 Tahun 2006 tentang Irigasi, PERMEN PUPR Nomor 14/PRT/M/2015 tentang Penetapan Status Daerah Irigasi serta Qanun Aceh Nomor 4 Tahun 2011 tentang Irigasi antara lain diarahkan untuk memperbaiki kinerja pengembangan dan pengelolaan jaringan irigasi berdasarkan kewenangan dan tanggungjawab pengelolaannya. Peningkatan kinerja dapat diupayakan melalui berbagai kegiatan, yang salah satunya adalah dengan memperbaiki sistem perencanaan. Mekanisme perencanaan yang baik sangat menentukan keberhasilan pencapaian tujuan, termasuk tujuan pengelolaan irigasi partisipatif. Oleh karena itu diperlukan instrumen perencanaan yang dapat memberikan masukan positif dalam rangka peningkatan kinerja pengelolaan irigasi partisipatif. Selain itu, PERMEN PUPR Nomor 09/PRT/M/2015 tentang Penggunaan Sumber Daya Air.

\section{KONSEP TRIANGULASI}

Konsep triangulasi diterapkan untuk mendapatkan informasi yang akurat dan valid. Konsep triangulasi pada dasarnya merupakan bentuk check dan re-check terhadap permasalahan. Konsep trianguasi pada penerapannya membutuhkan keterlibatan anggota dengan beragam disiplin ilmu dan pengetahuan, membutuhkan keberagaman latar belakang anggota, keberagaman sumber informasi, dan harus mampu memunculkan variasi pemecahan masalah. Beberapa hal yang harus diperhatikan dalam penerapan triangulasi di D.I Jambo Reuhat antara lain:

- Penggunaan variasi dan kombinasi metode pemahaman partisipatif petani terhadap kondisi irigasi, yaitu bersama dengan seluruh stakeholder memutuskan variasi dan kombinasi metode yang paling tepat sesuai dengan proses penyerapan teknologi tepat guna yang diinginkan dan cakupan informasi yang dibutuhkan dalam pengembangan program kegiatan.

- Menggali berbagai jenis dan sumber informasi, dengan menggunakan data terkalibrasi atau dapat juga dengan menggunakan data sebenar mungkin. Sumber data terutama data sekunder sedapat mungkin untuk dikalibrasi dan diverifikasi dengan menggunakan data yang sama atau serupa di tempat lain dan dapat dipertanggungjawabkan.

- Tim pelaksana program kegiatan merupakan tim dengan melibatkan seluruh stakeholder terkait dan multi disiplin ilmu, dengan maksud memberi sudut pandang yang beragam sehingga 
dapat memperkaya konsep pemecahan masalah dan metode pelaksanaan serta evaluasi. Keberagaman ini juga dapat memperkaya dan memperdalam informasi dan memberikan pengamatan yang mendalam dari berbagai sisi.

\section{Konsep Partisipatif}

Konsep partisipatif yang diharapkan untuk dapat diaplikasikan di D.I Jambo Reuhat diperoleh melalui hasil penyebaran angket dan diskusi pada FGD (Focuss Group Discusion). Pada pelaksanaan irigasi partisipatif, pelaksanaan operasi jaringan irigasi adalah upaya pengaturan air irigasi agar dapat dimanfaatkan secara efektif, efisien, dan merata melalui kegiatan membuka-menutup pintu bangunan irigasi, menyusun rencana tata tanam, menyusun sistem golongan, menyusun rencana pembagian air, melaksanakan kalibrasi pintu/bangunan, mengumpulkan data, memantau, dan mengevaluasi.

\section{Analisa SWOT}

Dalam penyusunan profil suatu daerah irigasi dipergunakan analisa SWOT untuk merumuskan strategi dan kebijakan yang akan digunakan. Analisa SWOT didasarkan pada :

- Memaksimalkan kekuatan (strengths) dan peluang (opportunities)

- Meminimalkan kelemahan (weaknesses) dan ancaman (threats)

Analisa SWOT adalah membandingkan faktor eksternal dan faktor internal. Faktor Eksternal terdiri dari : peluang (opportunities) dan ancaman (threats). Faktor internal terdiri dari : kekuatan (strengths) dan kelemahan (weaknesses).

\section{METODE YANG DIGUNAKAN}

Metode yang digunakan adalah penelitian deskriptif yang merupakan penelitian kasus dan penelitian lapangan (case study and field study). Dalam Studi ini juga disebarkan quesioner pada 12 (dua belas) P3A yang ada di D.I Jambo Reuhat.

Data yang diperlukan dalam studi ini berupa data primer dan data sekunder. Data primer diperoleh dari pengamatan langsung di lapangan berupa survei jaringan dan bangunan irigasi. Disamping itu juga dilakukan penyebaran quesioner pada 12 (dua belas) P3A. Wawancara dengan ketua P3A dan Keujeuruen Blang dilakukan untuk mendapatkan informasi permasalahan yang ada. Data sekunder diperoleh dari kajian terhadap undang-undang, peraturan-peraturan dan qanun terkait pengelolaan irigasi partisipatif.

Survei yang dilakukan berupa Survei aspek teknis (kondisi jaringan dan bangunan), survei aspek kelembagaan P3A, dan survei aspek sosial-ekonomi . Untuk lebih jelasnya dapat dilihat pada bagan alir penyelesaian studi seperti pada Gambar 2. 


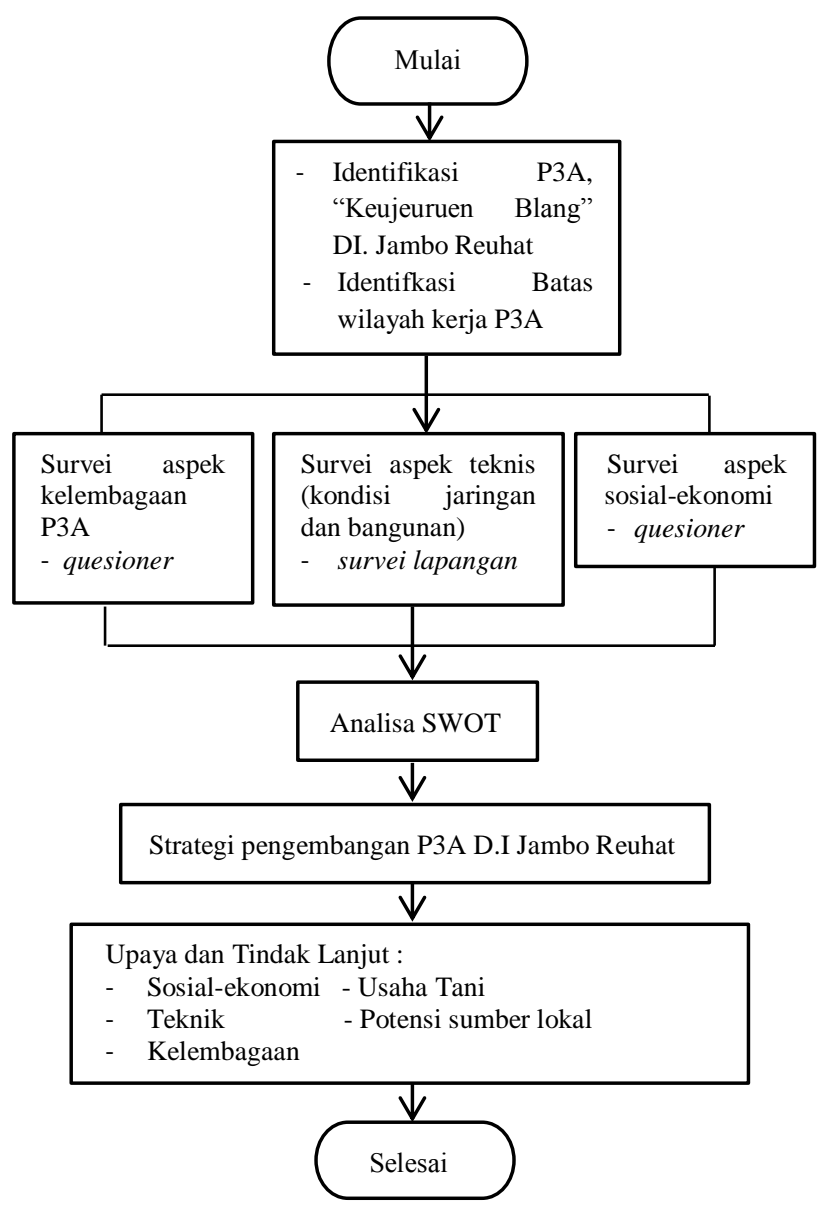

Gambar 1. Bagan Alir Penyelesaian Studi

\section{HASIL PEMBAHASAN}

Ditinjau dari segi pengelolaan Wilayah Sungai Terpadu, D.I Jambo Reuhat merupakan bagian dari Wilayah Sungai (WS) Jambo Aye. D.I Jambo Reuhat berada pada posisi $4,847^{\circ} \mathrm{LU}$ dan $97,689^{\circ} \mathrm{BT}$. Lokasi irigasi Jambo Reuhat berada dalam wilayah administrasi Kabupaten Aceh Timur yang meliputi Kecamatan Idi Rayeuk, Idi Tunong, Darul Ihsan dan Banda Alam. Untuk lebih jelasnya dapat dilihat pada Gambar 2. D.I Jambo Reuhat dapat diakses melalui jalan kabupaten dengan waktu tempuh \pm 40 menit dari Kota Idi. Kondisi jalan akses merupakan jalan dengan perkerasan aspal. Komoditas pertanian yang dikembangkan di D.I Jambo Reuhat adalah padi dan palawija.

Permasalahan yang terjadi di D.I Jambo Reuhat secara garis besar dapat dikelompokkan menjadi beberapa kelompok, yaitu:

1. Kondisi sosial ekonomi petani

2. Infrastruktur irigasi, meliputi kondisi bendung utama dan sistim saluran;

3. Penguatan kelembagaan secara berkesinambungan;

4. Kondisi usaha tani

5. Interaksi antar sumber lokal

\section{A. Permasalahan Sosial Ekonomi}

Berdasarkan hasil survei dan FGD, permasalahan terkait kondisi ekonomi di D.I Jambo Reuhat disajikan sebagai berikut:

1. Fasilitas penunjang kegiatan ekonomi produktif yang masih kurang, sehingga petani sering menggunakan waktu produktif untuk kegiatan yang tidak produktif;

2. Minimnya kesempatan bagi anak petani yang berusia muda untuk dapat melakukan kegiatan yang berkaitan langsung dan tidak langsung dengan kegiatan agro-indutri atau kegiatan lainnya yang dapat mendukung peningkatan ekonomi berbasis pertanian sawah;

3. Rendahnya tingkat swadana karena pendapatan ekonomi petani di D.I Jambo Reuhat yang masih sangat kecil atau rendahnya manfaat langsung yang dapat diperoleh oleh petani 


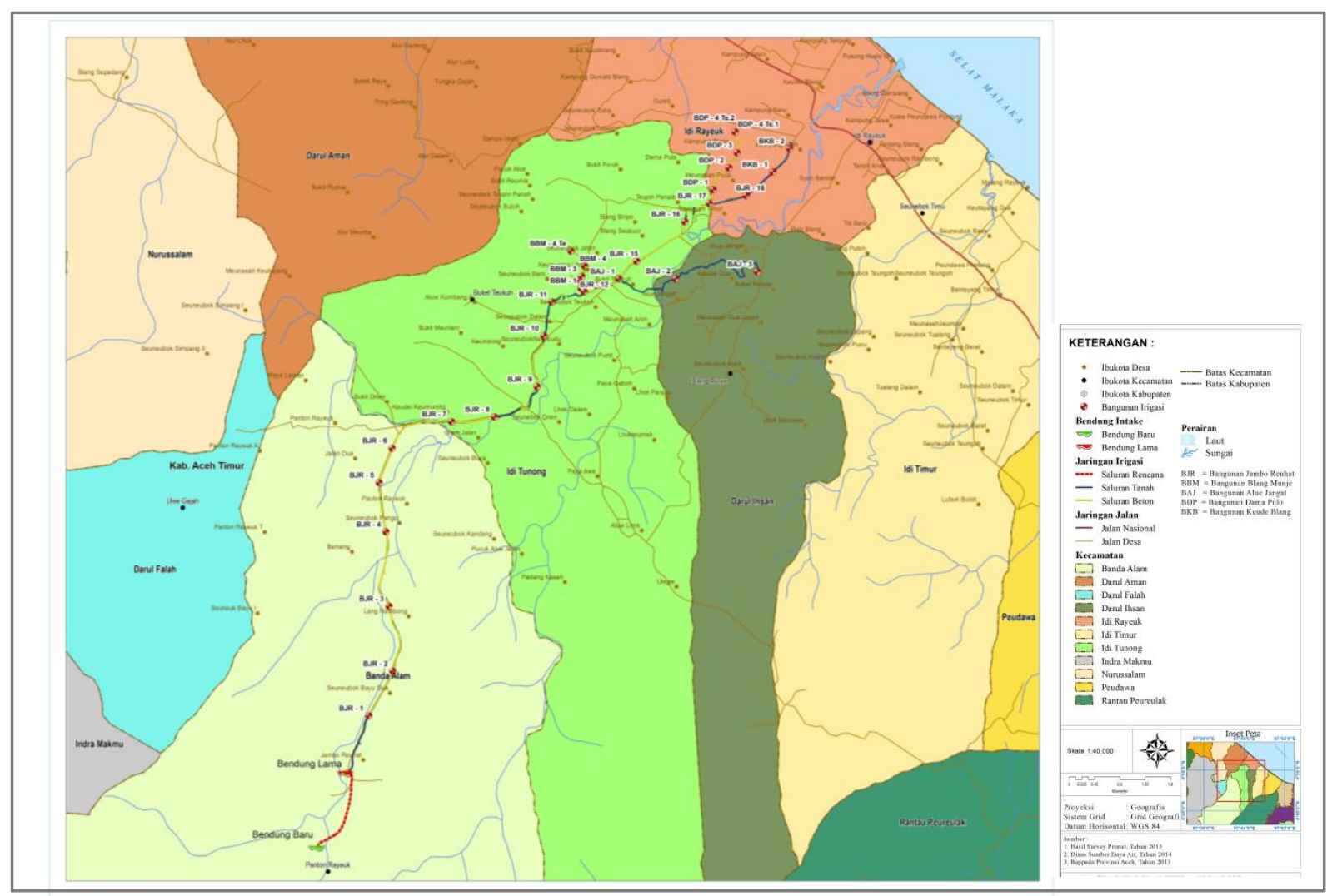

Gambar 2. Peta Jaringan Irigasi Jambo Reuhat

4. Pengaturan budidaya komoditas sawah yang belum dikelola secara optimal

5. Penurunan konstribusi petani akibat penurunan kegiatan usaha tani.

6. Peluang usaha ekonomi produktif yang dapat dikembangkan belum tergali secara maksimal, seperti usaha pengembangan komoditi unggulan yang mempunyai daya saing yang sangat baik dipasaran, intensifikasi pertanian, peningatan kemampuan penguasaan teknologi pra dan pasca panen, agronomi dan diversifikasi usaha tani.

\section{B. Permasalahan Teknik}

D.I Jambo Reuhat mengalami permasalahan dalam hal :

1. Ketersediaan air Krueng Idi yang tidak mencukupi terutama pada musim tanamII untuk mengairi 1.440 ha dari luas sawah yang ada 2.100 ha.

2. Pengoperasian bendung D.I Jambo Reuhat baru yang belum optimal.

3. Kondisi jaringan dan bangunan yang masih banyak membutuhkan penanganan teknis

4. Tumbuhnya tanaman liar di atas tanggul irigasi dan adanya bangunan di atas tanggul. 
5. Belum termanfaatkan potensi tampungan di sekitar D.I Jambo Reuhat sebagai usaha konservasi air.

6. Bendung lama yang telah mengalami penurunan kualitas layanannya

\section{Permasalahan Kelembagaan}

Permasalahan terkait kelembagaan yang berhasil diperoleh meliputi:

1. Perubahan pola pembinaan kelembagaan dari P3A ke Keujruen Blang memerlukan suatu lembaga yang berfungsi untuk mempercepat proses perubahan tersebut;

2. Daerah Irigasi Jambo Reuhat belum memiliki GP3A sehingga koordinasi kegiatan terlihat tumpang tindih antar P3A

3. Realisasi pelaksanaan AD/ART organisasi P3A di D.I Jambo Reuhat masih rendah

4. Kelembagaan P3A tidak pernah direvitalisasi, pengurus banyak yang telah tidak berada di Jambo Reuhat lagi. Namun demikian dalam pelaksanaan survei kelembagaan (tahun 2015), pihak P3A telah merevitalisasinya.

5. Aset kesekretariatan P3A belum ada, masih memanfaatkan fasilitas kantor Penyuluh Pertanian.

6. Struktur organisasi P3A belum menjadikan rapat anggota sebagai penguasa tertinggi

7. Dalam rangka pemberdayaan, P3A belum dilatih tentang teknis irigasi, Rencana Pembagian Air (RPA), Rencana Tata Tanam, Usaha Ekonomi Produktif,
Keuangan serta pengembangan jaringan kelembagaan.

8. Dalam rangka pemberdayaan, semua P3A belum dilatih tentang pelatihan PSETK dan bantuan Pengembangan Badan Hukum. Hanya 3 (tiga) P3A yang sudah memiliki SK Bupati, AD/ART dan kelengkapan lain yaitu P3A Bungong Jeumpa, P3A Karya Tani dan P3A Pulo Aceh. Namun Akte Notaris dari ketiga P3A sudah tidak ada lagi.

9. Realisasi pelaksanaan program kerja P3A sangat kecil

10. Pembuatan dokumen atau proposal serta pertanggung jawaban untuk pengurus P3A dirasa masih kurang.

11. IPI untuk seluruh wilayah kerja P3A relatif tidak ada susah untuk membayar.

12. Penguatan kerjasama seluruh instansi terkait dengan pengelolaan seluruh sumber daya di D.I Jambo Reuhat belum memberi dampak nyata dan belum ada forum silaturahmi antar Daerah Irigasi.

\section{Permasalahan Usaha Tani}

Permasalahan yang dijumpai pada kegiatan pengembangan usaha tani di D.I Jambo Reuhat meliputi:

1. Terkait dengan kegiatan pembinaan pertanian, kelompok tani memiliki peranan yang lebih dominan daripada P3A. Fungsi P3A lebih pada kegiatan pengelolaan infrastruktur penyediaan air yang dalam hal ini adalah saluran dan bangunan. Kondisi ini menimbulkan konflik antara para petani; 
2. Perlu dilakukan peningkatan terintegrasi secara optimal dengan penguasaan dan metode aplikasi kegiatan pertanian teknologi tepat guna pada tahapan pengolahan tanam, persiapan tanam sampai ke tahapan pasca panen;

3. Cara dan teknik dalam upaya peningkatan pendapatan petani belum memberikan hasil akhir yang lebih baik;

4. Belum terlaksananya pengembangan industri skala kecil berbasis agronomi dan potensi eksternal kawasan yaitu PPI Idi belum dimanfaatkan oleh kelompok P3A

5. Program ketahanan pangan belum memberikan nilai ekonomi bagi masyarakat.

\section{E. Permasalahan Potensi Sumber Lokal}

1. Terkait dengan permasalahan sumber local di D.I Jambo Reuhat, timbulnya permasalahan terkait:

2. Jumlah usia produktif di D.I Jambo Reuhat termasuk dalam kategori besar dengan tingkat pendidikan menengah. Potensi ini belum termanfaatkan dengan baik untuk kegiatan agro-ekonomi.

3. Jambo Reuhat memiliki kawasan penyangga perikanan yang sangat besar dan belum terinteraksi dengan baik.

4. Kegiatan pengembangan komoditi selain padi yang belum dilakukan secara optimal.

5. Pengaturan pola budidaya komoditi selain padi yang belum dikelola secara baik.

6. Potensi peternakan yang belum dikembangkan dengan baik dan belum

\section{ANALISA SWOT}

Analisa SWOT pada dasarnya merupakan teknik pendukung pengambilan keputusan dengan menganalisa potensi yang dimiliki, kelemahan dan kekurangan yang terjadi dan akan terjadi, kesempatankesempatan yang dapat muncul dan tantangan yang akan muncul pada pelaksanaan program kegiatan. Secara matrik, konsep analisa SWOT di D.I Jambo Reuhat disajikan sebagai berikut : 
Tabel 1. Konsep Analisa SWOT di D.I Jambo Reuhat

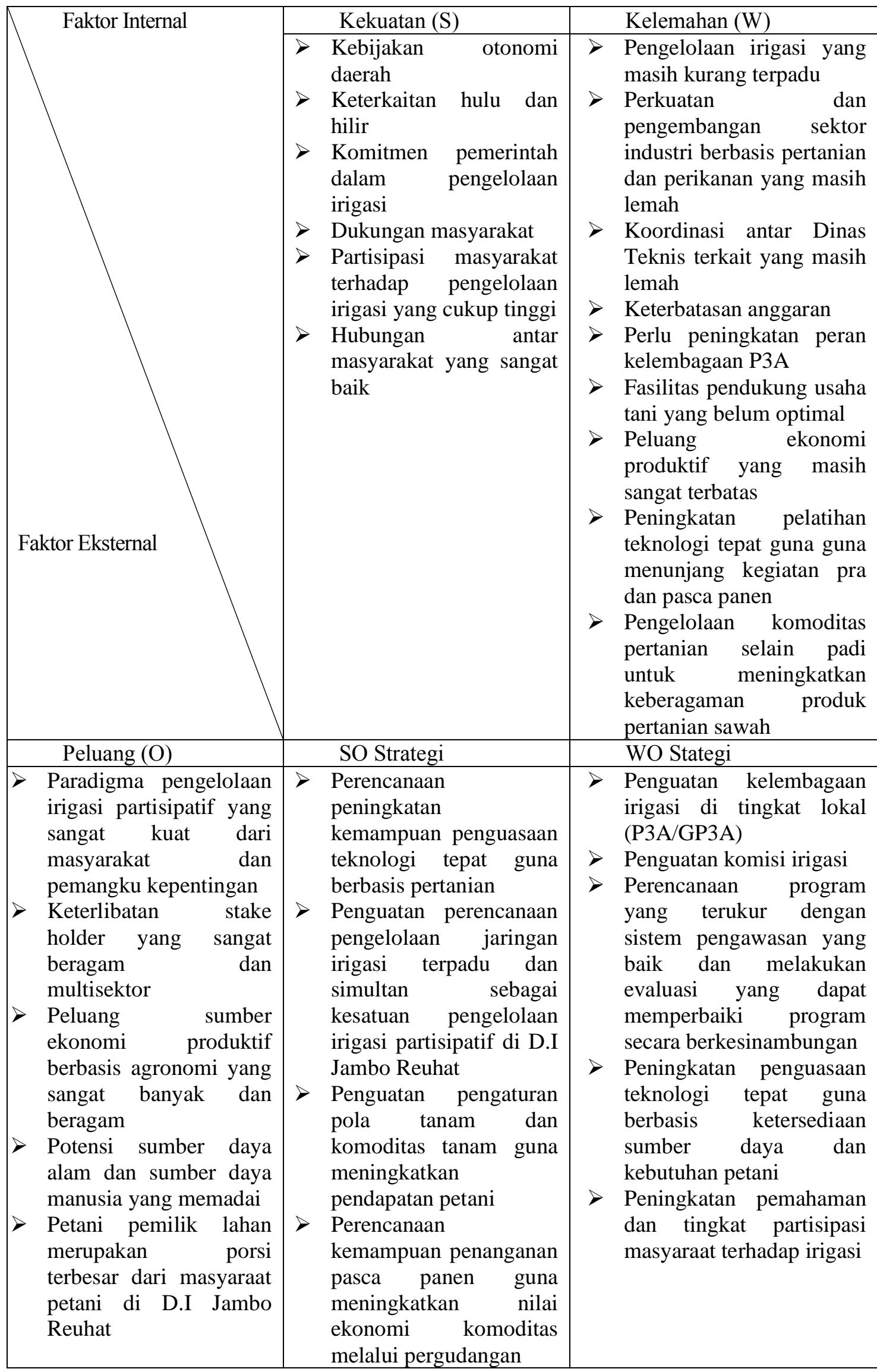




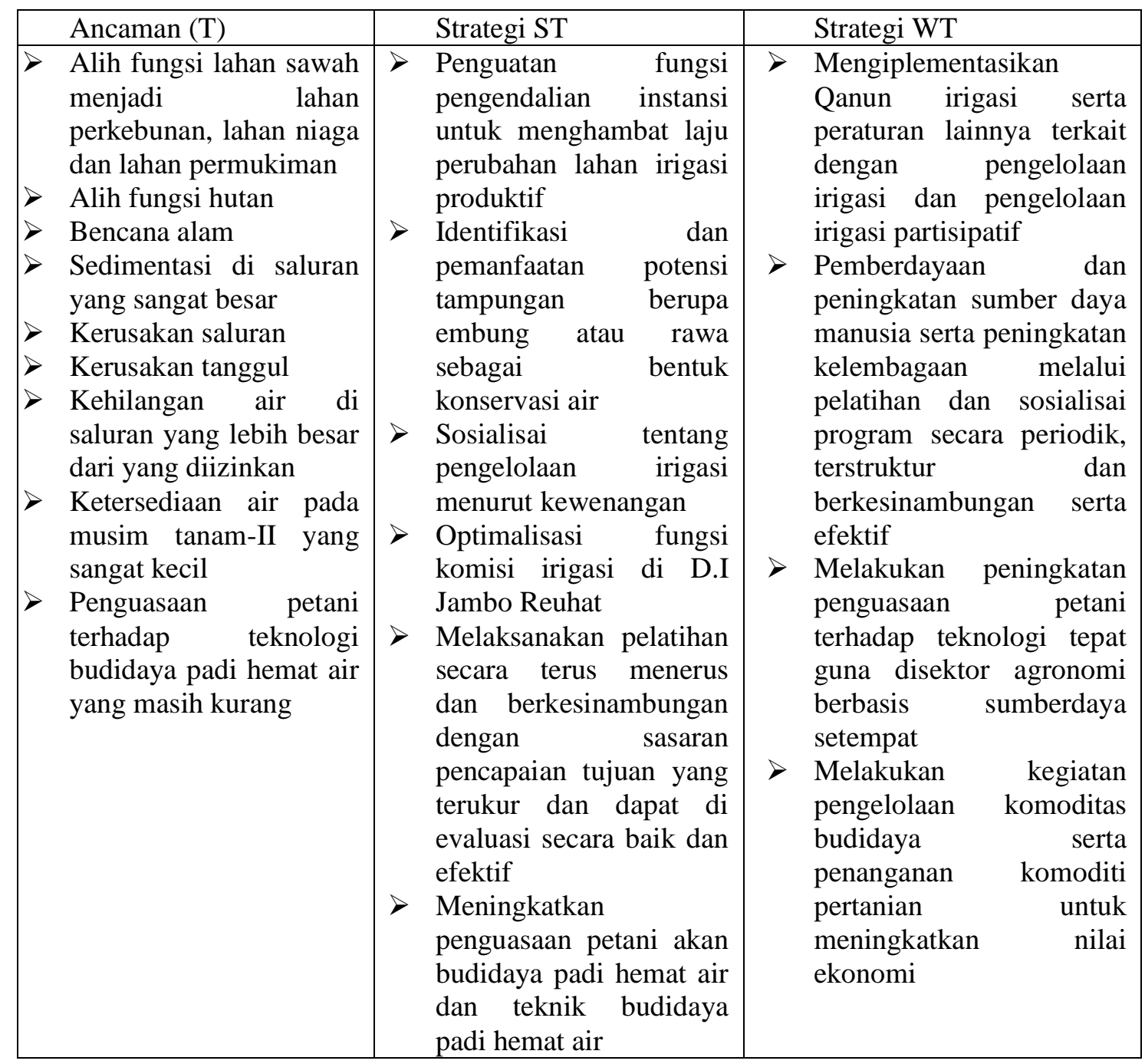

\section{A. Strategi SO}

Strategi SO merupakan strategi yang menggunakan seluruh kesempatan yang terdapat di D.I Jambo Reuhat untuk meningkatkan kondisi perekonomian petani. Fokus utama dalam penyusunan strategi SO di D.I Jambo Reuhat adalah sumber daya dan kelembagaan. Jika kedua komponen tersebut dapat dioptimalkan, akan diperoleh suatu strategi pengelolaan dan pengembangan D.I Jambo Reuhat yang baik. Dalam kajian ini, pelaksanaan strategi SO di D.I Jambo Reuhat meliputi :
1. Perencanaan peningkatan kemampuan penguasaan teknologi tepat guna berbasis pertanian.

2. Penguatan perencanaan pengelolaan jaringan irigasi terpadu dan simultan sebagai kesatuan pengelolaan irigasi partisipatif di D.I Jambo Reuhat

3. Penguatan pengaturan pola tanam dan komoditas tanam guna meningkatkan pendapatan petani

4. Perencanaan kemampuan penanganan pasca panen guna meningkatkan nilai ekonomi komoditas melalui pergudangan 


\section{B. Strategi ST}

Strategi ST disusun berdasarkan potensi ancaman yang terjadi di D.I Jambo Reuhat. Pada penyusunan strategi untuk menghadapi tantangan di D.I Jambo Reuhat, peran instansi terkait sangat dominan. Pola tantangan yang dihadapi oleh D.I Jambo Reuhat sebagian besar merupakan ancaman yang tidak dapat ditanggulangi oleh GP3A. Ancaman yang dihadapi oleh D.I Jambo Reuhat meliputi:

1. Alih fungsi lahan sawah menjadi lahan perkebunan, lahan niaga dan lahan permukiman

2. Alih fungsi hutan

3. Bencana alam

4. Sedimentasi di saluran yang sangat besar

5. Kerusakan saluran

6. Kerusakan tanggul

7. Kehilangan air di saluran yang lebih besar dari yang diizinkan

8. Ketersediaan air pada musim tanam-II yang sangat kecil

9. Penguasaan petani terhadap teknologi budidaya padi hemat air yang masih kurang

Pada ancaman diatas, terlihat bahwa alih fungsi lahan, bencana alam dan ketersediaan air menjadi isu yang sangat berkembang di masyarakat petani. Isu tersebut menjadi isu pokok permasalahan aktual di D.I Jambo Reuhat. Untuk mengatasi ancaman tersebut, strategi ST yang disusun meliputi:

1. Penguatan fungsi pengendalian instansi untuk menghambat laju perubahan lahan irigasi produktif

2. Identifikasi dan pemanfaatan potensi tampungan berupa embung atau rawa sebagai bentuk konservasi air

3. Sosialisai tentang pengelolaan irigasi menurut kewenangan

4. Optimalisasi fungsi komisi irigasi di D.I Jambo Reuhat

5. Melaksanakan pelatihan secara terus menerus dan berkesinambungan dengan sasaran pencapaian tujuan yang terukur dan dapat di evaluasi secara baik dan efektif

6. Meningkatkan penguasaan petani akan budidaya padi hemat air dan teknik budidaya padi hemat air.

\section{Strategi WO}

Dalam perwujudan analisa sistem manajemen irigasi, kelemahan pada suatu daerah irigasi sering sekali muncul dalam bentuk yang serupa akan tetapi memiliki dampak yang berbeda. Kelemahan dalam pengelolaan irigasi sering sekali diartikan sebagai kelemahan kelembagaan bahkan instansi secara vertikal. Hal ini terkait dengan tujuan pengelolaan irigasi oleh instansi terkait yang terkadang tidak berkesinambungan dan/atau efektif. Pada hasil kajian terhadap D.I Jambo Reuhat, kelemahan penguatan irigasi juga sangat ditentukan oleh kondisi sumber daya alam dan interaksi antar sektor di Kabupaten Aceh Timur dan Provinsi Aceh. Strategi WO disusun berdasarkan evaluasi terhadap kelemahan yang ditemui pada pengelolaan dan peningkatan kondisi D.I Jambo Reuhat. Secara umum, kelemahan yang teridentifikasi di D.I Jambo Reuhat 
diperoleh melalui kegiatan FGD dan survei lapangan. Faktor-faktor yang menjadi kelemahan di D.I Jambo Reuhat meliputi:

1. Pengelolaan irigasi yang masih kurang terpadu

2. Perkuatan dan pengembangan sektor industri berbasis pertanian dan perikanan yang masih lemah

3. Koordinasi antar Dinas Teknis terkait yang masih lemah

4. Keterbatasan anggaran

5. Perlu peningkatan peran kelembagaan P3A

6. Fasilitas pendukung usaha tani yang belum optimal

7. Peluang ekonomi produktif yang masih sangat terbatas

8. Peningkatan pelatihan teknologi tepat guna, untuk menunjang kegiatan pra dan pasca panen

9. Pengelolaan komoditas pertanian selain padi untuk meningkatkan keberagaman produk pertanian sawah

Untuk mengatasi kelemahan yang terjadi, program yang disusun meliputi :

1. Penguatan kelembagaan irigasi di tingkat lokal P3A

2. Pembentukan GP3A yang merupakan kumpulan dari beberapa P3A

3. Penguatan komisi irigasi

4. Perencanaan program yang terukur dengan sistem pengawasan yang baik dan melakukan evaluasi yang dapat memperbaiki program secara berkesinambungan.

5. Peningkatan penguasaan teknologi tepat guna berbasis ketersediaan sumber daya dan kebutuhan petani

6. Peningkatan pemahaman dan tingkat partisipasi masyarakat terhadap irigasi

\section{Strategi WT}

Penyusunan strategi WT adalah penyusunan strategi dengan memanfaatkan tantangan untuk menghindari ancaman yang ada. Berdasarkan tantangan dan ancaman yang muncul, program untuk memanfaatkan tantangan sebagai keuntungan mengatasi ancaman meliputi :

1. Mengiplementasikan Qanun irigasi serta peraturan lainnya terkait dengan pengelolaan irigasi dan pengelolaan irigasi partisipatif

2. Pemberdayaan dan peningkatan sumber daya manusia serta peningkatan kelembagaan melalui pelatihan dan sosialisai program secara periodik, terstruktur dan berkesinambungan serta efektif

3. Melakukan peningkatan penguasaan petani terhadap teknologi tepat guna disektor agronomi berbasis sumberdaya setempat

4. Melakukan kegiatan pengelolaan komoditas budidaya serta penanganan komoditi pertanian untuk meningkatkan nilai ekonomi 


\section{KESIMPULAN}

Dari hasil survei lapangan dan analisa SWOT dapat disimpulkan bahwa diperlukan pemberdayaan P3A dan Keujeuren Blang di D.I Jambo reuhat serta perbaikan teknis jaringan dan bangunan. Beberapa hal yang penting dilakukan dalam mengembangkan Daerah Irigasi jambo Reuhat diantaranya :

1. Peningkatan peluang usaha ekonomi produktif yang dapat dikembangkan secara maksimal melalui intensifikasi pertanian, peningatan kemampuan penguasaan teknologi pra dan pasca panen, agronomi dan diversifikasi usaha tani.

2. Peningkatan status $\mathrm{P} 3 \mathrm{~A} /$ Keujruen Blang menjadi berbadan hukum dan memiliki legalitas dalam setiap pelaksanaan pekerjaan yang berhubungan dengan peningkatan kinerja D.I Jambo Reuhat.

3. Penggunaan Unsur Kearifan Lokal "Keujruen Blang" di D.I Jambo Reuhat

4. Revisi dan sosialisasi AD/ART bersama pegurus dan anggota P3A yang difasilitasi oleh Team Penyempurnaan Organisasi Keujruen Blang.

5. Fasilitasi pelatihan P3A tentang Teknis Irigasi, Rencana Pembagian Air (RPA), Rencana Tata Tanam, Usaha Ekonomi Produktif, Pengelolaan IPI.

6. P3A perlu menyusunan SOP terkait dengan wilayah kerja dan tata cara pelaksanaannya agar hubungan yang harmonis dengan kelompok tani tetap terjaga. Hal ini perlu didiskusikan dengan kelompok tani yang difasilitasi oleh
Dinas Pertanian, Dinas Pekerjaan Umum dan Komisi Irigasi serta Keujruen Blang.

7. Pengembangan potensi peternakan untuk mendukung kegiatan pertanian dan terintegrasi secara optimal dengan kegiatan peningkatan ekonomi petani.

8. Pelatihan-pelatihan mengenai peningkatan hasil panen dan ekonomi petani di D.I Jambo Reuhat secara berkelanjutan.

\section{Ucapan Terimakasih}

Terimakasih kepada BAPPEDA Aceh Bidang Sarana dan Prasarana yang telah melibatkan penulis dalam program penyusunan profil Daerah Irigasi Jambo Reuhat Tahun 2015.

\section{DAFTAR PUSTAKA}

Anonim.1974. Undang-undang No. 11 Tahun 1974 tentang Pengairan.

Anonim.2004. Undang-Undang No. 32 Tahun 2004 tentang Pemerintahan Daerah.

Anonim.2004. Undang-Undang No. 25 Tahun 2004 tentang Sistem Perencanaan dan Pembangunan Nasional.

Anonim.2009. Undang-Undang No. 41 Tahun 2009 tentang Perlindungan Lahan Pertanian Pangan Berkelanjutan.

Anonim.2007. Peraturan Pemerintah No. 38 Tahun 2007 tentang Pembagian Urusan Pemerintahan Antara Pemerintah, Pemerintahan Daerah 
Provinsi, dan Pemerintahan Daerah

Kabupaten/Kota.

Anonim.2006. Peraturan Pemerintah No. 20 Tahun 2006 tentang Irigasi.

Anonim.2011. Qanun Aceh Nomor 4 Tahun 2011 tentang Irigasi

Anonim.2015. PERMEN PUPR Nomor 14/PRT/M/2015 tentang Penetapan Status Daerah Irigasi

Anonim.2015. PERMEN PUPR Nomor 09/PRT/M/2015 tentang Penggunaan Sumber Daya Air. 